\title{
IMAGENS DA MULHER NA CIÊNCIA E NA FICÇÃO DE AFRÂNIO PEIXOTO: A ESFINGE E ELEMENTOS MEDICINA LEGAL EM DEBATE
}

\author{
Maria de Lourdes Silva ${ }^{1}$ \\ Helena Maria Alves Moreira ${ }^{2}$ \\ Universidade do Estado do Rio de Janeiro - UERJ
}

\section{RESUMO}

Este trabalho analisa as formas como a mulher é apresentada em duas obras de Afrânio Peixoto (1876-1947) escritas entre 1910-1: o romance A Esfinge e o manual didático, Elementos de Medicina Legal. Os contemporâneos do médico baiano costumavam aclamar sua competência profissional e inteligência solicitando circulação e adesão do polígrafo à rede institucional constitutiva do aparato administrativo estatal, corporativo ou editorial, aos quais Afrânio selava alinhamento através de sua obra escrita. A educação da mulher, o seu lugar na sociedade e os papeis a ela cabíveis são temas que ocupam o autor e filtro de nossa investigação nas obras citadas. Formado na tradição da ciência criminológica do final do século XIX e início do XX, a relevância do presente trabalho está em refletir sobre como a literatura "peixotiana" traz à cena as teorias eugenistas e os preconceitos sociais pelas caracterizações de suas personagens, forçando-nos a repensar a genialidade atribuída ao autor e os limites entre a poética literária e a escrita científica em sua obra. Como resultado desse estudo, indicamos as imprecisões entre ciência e moral no pensamento do autor, o que acarreta manutenção de explicações organicistas justificando o lugar da mulher na sociedade.

Palavras-chave: Afrânio Peixoto; Educação da mulher; Literatura; Criminologia.

\section{WOMAN PICTURE IN SCIENCE AND FICTION THE AFRÂNIO PEIXOTO: A ESFINGE AND ELEMENTOS MEDICINA LEGAL IN DISCUSSION.}

\begin{abstract}
This work analyzes the ways in which the woman is presented in two books of Afrânio Peixoto (1876-1947) written between 1910and 1911: the romance "A Esfinge" and text book, "Elementos de Medicina Legal". Doctor's contemporaries used to acclaim his professional competence and intelligence requesting circulation and adhesion the polygraph the institutional network the institutional network the state administrative structure, corporative or editorial, to which Peixoto sealed alliance through your written work. The women's education, your place in society and the papers her applicable are themes that occupy the author and our research filter in this works. Formed in the tradition of criminal science from the late 19th and early 20th centuries, the relevance of this work is to reflect on how literature "peixotiana" brings to the scene eugenics theories and social prejudices characterizations of his characters, forcing us to thought the genius that were attributed the author and the boundaries among then poetics of literary and scientific writing in his work. As a result of this study indicated the inaccuracies between science and morality in the author's thought that lead to maintenance of organicist explanation justifying the place of women in society.
\end{abstract}

Keywords: Afrânio Peixoto; Women's education; Literature; Criminology. 


\section{IMÁGENES DE LA MUJER EN LA CIENCIA Y EN LA FICCIÓN DE AFRÂNIO PEIXOTO: A ESFINGE Y MEDICINA LEGAL EN DEBATE}

\section{RESUMEN}

Este trabajo analiza las formas como la mujer es presentada en dos obras de Afrânio Peixoto (1876-1947) escritas entre 1910 e 1911: el romance "A Esfinge! y el manual didáctico, "Elementos de Medicina Legal". Los contemporáneos del médico nascido en Bahia, acostumbraban aclamar su competencia profesional e inteligencia solicitando circulación y adhesión del polígrafo a la rede institucional constitutiva del aparato administrativo estatal, corporativo o editorial, a los cuales Afrânio sellaba aliñamiento a través de su obra escrita. La educación de la mujer, su lugar en la sociedad y los papeles a ella adecuados son temas que ocupan el autor y filtro de nuestra investigación en las obras citadas. Formado en la tradición de la ciencia criminológica del final del siglo XIX e iniciación del siglo XX, La relevancia de este trabajo es reflexionar sobre cómo "peixotiana" literatura tras a la cena las teorías eugenistas y los prejuicios sociales por las caracterizaciones de sus personajes, nos obligando a repensar la genialidad atribuida al autor y los límites entre la poética literaria y la escrita científica en su obra. Como resultado de este estudio indicaron las imprecisiones entre la ciencia y la moral que conducen al mantenimiento de la explicación organicista justificando el lugar de la mujer en la sociedad.

Palabras- llave: Afrânio Peixoto; Educación de la mujer; Literatura; Criminología.

\section{1 - Introdução}

Este trabalho procurou analisar em duas obras, escritas por um Afrânio Peixoto jovem, a relação entre o trânsito de imagens da mulher da ficção à ciência. Elementos de Medicina Legal é o livro didático que resulta do curso ministrado na Faculdade de Medicina do Rio de Janeiro, a partir de 1907, na cadeira de Medicina Legal e Higiene, mas, sobretudo, do longo contato mantido com essa especialidade médica desde a Bahia, onde fez sua tese de doutoramento, Epilepsia e Crime, em 1897 e onde também deu início às suas atividades docentes, como professor substituto na Faculdade de Direito da Bahia, em 1901, na cadeira de Medicina Pública, a mesma para qual seria nomeado na Faculdade de Direito do Rio de Janeiro, em 1913 (LOPES, 1999, p. 320-1). A Esfinge, seu segundo romance, foi escrito em 1910, no Egito, para justificar candidatura e eleição "à revelia" do próprio à Academia Brasileira de Letras. Publicados no mesmo ano de 1911, estes trabalhos, embora guardem distância quanto ao gênero discursivo e versem sobre temáticas distintas, operam representações similares sobre a mulher no interior das modalidades narrativas eleitas.

Nosso objetivo foi observar, nas duas obras, o ajuste e a adequação das ideias do autor sobre a mulher no interior dos gêneros discursivos utilizados. Consideramos que os discursos são modos de expressão de posições pré-definidas e orientadas (BAKHTIN, 1997), por isso, as injunções dos modelos narrativos através dos quais se efetuam não alteram a essencialidade da proposição inicial:

A variedade dos gêneros do discurso pressupõe a variedade dos escopos intencionais daquele que fala ou escreve. O desejo de tornar seu discurso 
inteligível é apenas um elemento abstrato da intenção discursiva em seu todo. (BAKHTIN, 1997, p. 291).

A nova concepção de história que se estabelece a partir da década de 1960 consagrou a ideia de que a realidade social e cultural é constituída pelos homens em suas inter-relações cotidianas, deliberadas ou não. Ao tomar a cultura nos termos utilizados pela antropologia, essa abordagem desfaz a ideia do que é central e periférico na história e instaura um intrincado jogo de troca e negociação na construção de um dado contexto socio-histórico (BURKE, 1992). Isto implica em reconsiderar a posição das elites letradas e dirigentes enquanto lócus de produção de ideias e valores, redimensionando seu papel na mudança social.

Assim, ao analisar livros, enquanto materialidade de projetos civilizadores de grupos específicos é preciso levar em conta a imersão destes no conjunto social sem, contudo, desconsiderar sua função específica a fim de poder percebê-los no aparato dos acordos e por seus processos instituintes. E, neste sentido, ver estes livros como fontes que projetam propostas de acordos, tanto mais ou menos passíveis de aceitação pelo que expressam de ajustes - quando consideramos as ideias em voga, anteriores à publicação destes - e também de realização antecipada em conformidade com o que apostam conquistar. Assim, consideramos, com Peter Burke, necessário "praticar a crítica das fontes, perguntar por que um dado texto ou imagem veio a existir, e se, por exemplo, seu propósito era convencer o público a realizar alguma ação" (BURKE, 2005, p. 32).

O entendimento deste ponto impõe problematizar a estrutura sociocultural de produção das obras, procurando compreendê-la enquanto ambiente gerador e também receptor destas e, do mesmo modo, observar no registro da autoria as contingências do entorno e da autonomia relativa da operação criativa exercida, que nos conduz à consideração dialética da relação autor-obra-meio. Ou, como diz Antonio Candido, A obra, por sua vez, vincula o autor ao público, pois o interesse deste é
inicialmente por ela, só se estendendo à personalidade que a produziu depois de
estabelecido aquele contacto indispensável. Assim, à série autor-público-obra,
junta-se outra: autor-obra-público. Mas o autor, do seu lado, é intermediário
entre a obra, que criou, e o público, a que se dirige; é o agente que desencadeia o
processo, definindo uma terceira série interativa: obra-autor-público.
(CANDIDO, 2005, p. 47).

No nosso caso, o público foi inferido dos direcionamentos do autor, mas detivemo-nos na compreensão de que o meio é mais abrangente que o público por mais que seja difuso e acene para distintos alvos. De todo modo, este não é um exercício fácil e, neste estágio de nossa investigação, apenas apresentamos o esforço e seus percalços mais do que os resultados.

Particular atenção é dada à composição da construção da personalidade individual do autor estudado. Forjada a partir de estímulos voltados a reafirmar sua "inteligência incomum", se considerarmos procedente as narrativas dos seus biógrafos (COUTINHO, 1962; GOUVEIA, 1976; RIBEIRO, 1950), podemos observar o quanto a estrutura de poder que se estabelece na Primeira República reforça e atrai homens da envergadura de Afrânio Peixoto, ao legitimar seus potenciais e encarregá-los de compromissos à nação. Neste sentido, nossa primeira hipótese é a de que a trajetória de Afrânio guarda estreita 
relação com a dinâmica de empreendimentos e necessidades das elites dirigentes, cujos valores beneficiam a ele, que por sua vez se vê estimulado a responder a contento. Se considerarmos a condição de origem e a situação por ele alcançada ao longo de sua vida, veremos como se efetiva a transposição de "certo tipo de relação outsider-establishment" (ELIAS, 1995) e, mais importante, como esse traço de sua trajetória consolida sua personalidade à medida que faz convergir às ambições pessoais os interesses dos grupos estabelecidos. Esse registro relativiza os brados a este "homem de gênio" 3 que não se vê a si mesmo e tampouco é dito nessa rubrica pelo que ela implica e suscita, embora se valha do que esta lhe angaria.

É bastante cômodo ser tomado como uma inteligência incomum, um homem com talentos múltiplos capaz de filiar-se a diferentes sociedades científicas por requisição do grupo de homens de ciências e letras, ao qual passa a pertencer.

\section{2 - O gênio de Afrânio Peixoto}

Quando olhamos para o início do século passado e observamos o trânsito de homens como Afrânio Peixoto (1876-1947), indagamos a respeito de sua capacidade para transitar por áreas tão distintas como medicina, direito, educação, história, literatura, política e administração pública. Mesmo quando consideramos o quadro dos "homens de ciências e letras" da Primeira República brasileira, ao qual Afrânio pertenceu, percebemos que a consistência das entradas de Afrânio nas diversas esferas excede a dos seus contemporâneos. Admirado por estes, não são raros os autores que destacam sua erudição e loquacidade.

É certo que Afrânio agregou e dominou um extenso conjunto de conhecimentos em áreas distintas - experiência não estranha aos seus contemporâneos, homens que, a despeito do múltiplo pertencimento, lidavam com um conjunto de informações e conhecimentos incomparavelmente mais enxuto e organizado do que aquele a que estamos expostos atualmente e com o qual temos que trabalhar. E, sob esse ponto de vista, o extraordinário da polimorfia de Afrânio Peixoto, que resulta do contato gradual e sucessivo com esses conhecimentos ao longo dos 70 anos de sua vida, é relativizado ante a inexistência dos múltiplos meios midiáticos atuais e mais a profusão das produções oriundas das diversas instituições acadêmicas e suas pós-graduações conectadas em redes.

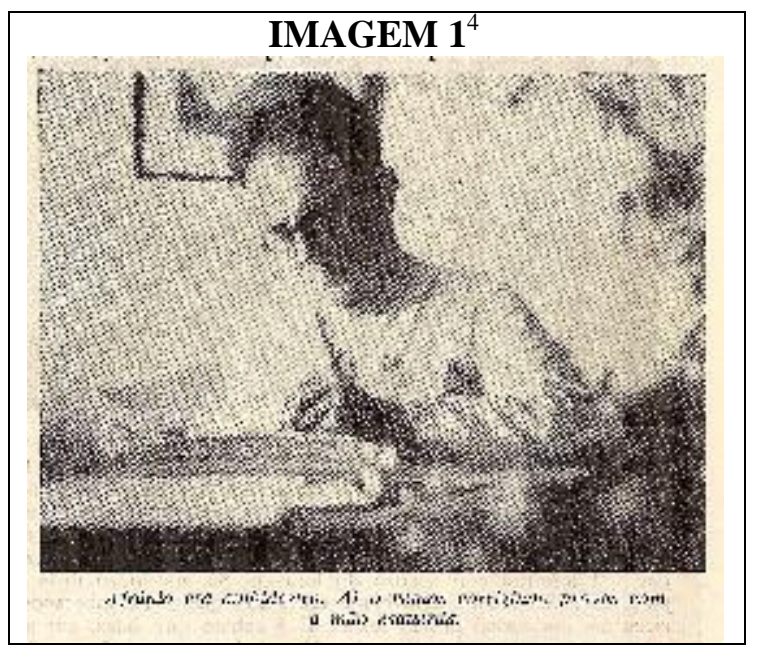

Se pensarmos na formação acadêmica de outras épocas, veremos que talvez fosse mais adequado dizer que os homens do tempo do Afrânio ${ }^{5}$, instruídos antes do advento da universidade entre nós, estão dando continuidade àquele processo formativo nomeado "enciclopédico" pela Ilustração e ao qual, eles mesmos, identificam como indispensável aos "eruditos". Embora Afrânio defenda, com as novas correntes pedagógicas, a especialização na formação, tal posição parece-nos destinar-se ao conjunto mediano da sociedade, não se aplicando aos homens na 
condição dele.

No caso do Afrânio, tal erudição não chama mais atenção, nos dias de hoje, do que os usos que o autor fez dos conhecimentos adquiridos e das informações acessadas, tal como destacam José Gondra \& José Sooma Silva (2011). Tais conhecimentos e tão vasta produção somente fazem sentido se amparados na trajetória desse homem, tido por alguns contemporâneos como afeito ao diletantismo ${ }^{6}$, enquanto condição que lhe assegura ingresso no staff dirigente. Homem nascido na elite periférica nordestina de origem burguesa, neto de imigrante português atraído à Chapada Diamantina pela descoberta de reservas de diamantes, filho de comerciante de diamantes, Afrânio cresce concomitante à ampliação dos quadros da administração pública nas esferas federal, estadual e municipal. Ao conseguir fazer confluir seus talentos pessoais às necessidades da elite dirigente da Capital Federal, ele é progressivamente levado às entranhas do poder, o qual percorre em praticamente toda extensão de sua malha, aderido ao grande propósito dos higienistas, orientado por suas ambições pessoais e, ao mesmo tempo, pelas necessidades do establishment, sobretudo como médico-legista e professor, corroborando com a compreensão de Eliane Lopes sobre o autor quando afirma "o quão intricadas estavam a educação, a medicina e o direito na formulação de soluções para os problemas brasileiros" (1999, p. 321). A chancela de médico higienista e legista conferiu-lhe autoridade para pertencimentos diversos na organização social e, do mesmo modo, permitiu mistificar sua origem outsider, conferindo-lhe uma aura de competência e talentos extraordinários. Este aspecto é crucial à compreensão da interdependência que o autor selou entre si, instituições e pessoas do seu tempo ${ }^{7}$.

Desde estudante de medicina na Bahia, ficou-lhe a reputação de aluno notável, dado às ousadias. Afrânio Coutinho (1962) destaca a fama do aluno do Colégio Florêncio e os "seus exames magistrais" nos preparatórios. Como ambidestro, nosso autor aparece em foto corrigindo provas com a mão esquerda (Ver Imagem 1), à maneira dos compêndios de medicina à época, que costumavam trazer ilustrações (desenhos, fotos, pinturas) demonstrando o incomum.

Afrânio Peixoto cultiva a reputação de homem incomum por expedientes diversos. A Homero Senna (1968), em entrevista concedida em 1945, diz sobre seu tempo de estudante na Bahia:

\begin{abstract}
(...) quando estudante, pelo desejo de aparecer, de me tornar conhecido, foi um moço dos mais extravagantes e mistificadores. Você não pode imaginar como sou grato à "boa terra" por me haver perdoado todas as estroinices do meu tempo de rapaz. E para escandalizar o honesto público, que eu fazia? Numa época de respeitabilidade e de costumes rígidos, na qual até mesmo os moços usavam roupas escuras e graves, (...) eu alarmava as populações saindo à rua sem chapéu. Sou, portanto - diz-me sorrindo - um precursor desta moda que veio, afinal, a se tornar tão popular. (SENNA, H. 1968, p. 77).
\end{abstract}

Afrânio era dado a exibir-se e a chamar atenção para si, não apenas por suas vestes e modos incomuns, mas pelo apelo contestatório como costumava expor suas ideias em ambientes sabidamente adverso, como demonstra seus biógrafos e estudiosos (SENNA,

Contudo, ele parece ter sabido compensar as "extravagâncias" com o seu desempenho enquanto aluno e também professor, fundindo ambas ao parecer estar sempre "inovando": 
Quando aqui chegou em 1902, para disputar o famoso concurso de Medicina Legal e Higiene, na Faculdade de Medicina, que lhe daria renome imediato e posição contraditória nos meios científicos (...), impôs-se de modo fulminante. Entrou na Faculdade como um conquistador, impertinente, mas competente, fazendo provas práticas que desconcertava os mestres e revelavam um perito experimentado, onde se julgava encontrar apenas um diletante engenhoso e versátil. Foi assim toda a vida. (RIBEIRO, L. 1950, p. 13.).

Ao chegar ao Rio, ingressa como Inspetor de Saúde pública, em 1902; em 1904, assume como Diretor do Hospital Geral dos Alienados, e, no início de 1907, assume a direção do Serviço Médico Legal da Polícia, quando participa da reforma do serviço médico-pericial. Em 1905, inscreve-se para concorrer a uma vaga na Faculdade de Medicina, mas como o concurso fora adiado, ele faz longa viagem pela Europa, percorrendo 10 países, acompanhado do filho do então presidente da república, Rodrigues Alves (MAIO, 1994, p. 76). De volta, ao envolver-se com as reformas públicas, Afrânio se põe em contato direto com os grupos de intelectuais que transitavam pelas esferas do poder. O convívio pelo ofício na Capital Federal o colocava em contato constante com políticos, magistrados, professores, médicos, intelectuais de variados matizes. Na rotina de saraus, jantares, almoços e reuniões sociais diversas, Afrânio tecia acordos, ouvia conselhos e sedimentava sua trajetória. O livro Elementos de Medicina Legal nasce como orientação do livreiro Francisco Alves durante uma conversa onde Afrânio lhe falara sobre o porquê de ainda não conhecer a Europa:

Respondi-lhe que me faltavam meios; os meios se adquirem pelo trabalho. - "Por que não escreve um livro didático que lhe dê para isso?" Como não compreendesse bem, explicou-me que o compêndio de Medicina Legal de Souza Lima era inabordável e o Manual que lhe juntasse à doutrina algumas observações, por fôrça seria bem recebido. Uma primeira edição de um livro didático poderia dar-me a cobiçada viagem. (...). Pus-me a escrever o livro... (DICIONÁRIO HISTÓRICOBIOGRÁFICO DAS CIÊNCIAS DA SAÚDE NO BRASIL).

Afrânio sabia aproveitar as oportunidades. Segundo Eliane Lopes, ele era "movido por um desejo confesso de aparecer e fazer carreira" (199, p. 321), motivação maior de sua mudança da Bahia para o Rio de Janeiro, em 1902. Afrânio chega à Capital às vésperas do início do "Bota-abaixo", do prefeito do Rio de Janeiro, Pereira Nunes, quando a cidade se encontra em momento de mudanças intensas, quando a produção literária da cidade já consegue registrar de modo crítico à proximidade da literatura com o poder e com a existência de uma literatura que pouco expressa a realidade da sociedade. Neste sentido, João do Rio e Lima Barreto, por exemplo, trazem em suas obras, cada um a sua maneira, produções que se ocupam de outras esferas da vida social, com temas importantes para questionar a realidade social e o projeto de desenvolvimento nacional, entendendo que o que está em causa é a construção de uma estética literária que mostre certa autonomia com relação ao fazer literário da intelectualidade tradicional dos bacharéis e discuta a vida brasileira.

Tal proposição aparece como clímax de um processo que remonta ao século anterior e antecede a República, mas que nesta se amplia e consolida intenções de mudanças à nação, com propósito de filiá-la ao movimento modernizador da Europa e dos Estados Unidos. A proposta de "construir a nação e remodelar o Estado" é, segundo Nicolau Sevcenko (2003, p. 103), condição compulsória orientada pelos princípios do cientificismo e do 
liberalismo ${ }^{8}$, materializados na modernização da capital do país como expressão da intenção de acompanhar as nações industrializadas e na necessidade de conhecer seu povo e território a fim de, respectivamente, controlá-lo e ocupa-lo. Havia, assim, uma intenção real de conhecer o país, o que foi feito sob diversas orientações de interesses. No centro da questão, está o papel dos intelectuais na programação do projeto político que lançaria a nação no cenário internacional.

A literatura já algum tempo se afastava da boemia underground, voltando-se a cumprir um papel de maior proximidade do poder. O romance, mais do que a poesia, escrito no formato de folhetins publicados nos diários da cidade, cativa leitores fieis e suscetíveis à força pedagógica destes (MATTA, 2003, p. 261). Especialmente após a fundação da Academia Brasileira de Letras, escritores e jornalistas passam a exigir profissionalização (MATTA, 2003, p. 266). Arte e ofício se fundem como campo de criação laborativa, indo ao encontro das pretensões das elites da cidade civilizada e mundana - e nesta rubrica leiase liberal, democrática, progressista e, sobretudo, laica -, inclinada à reprodução dos hábitos parisienses, criando posturas divergentes entre os homens das letras de então. Ao reproduzir a vida de homens e mulheres da Capital Federal, a literatura pode fazê-lo pelo registro do mundo dos salões, cafés, teatros etc., ou dos botecos, becos, bordéis e cabarés, periferias e subúrbios. A filiação a qualquer dessas linhas evidencia posicionamentos políticos precisos, alguns forjados compulsoriamente ${ }^{9}$, dando mostras de que a escrita literária contava com seus críticos, o que não era exatamente uma novidade quando consideramos que para esse Brasil novo os homens atraídos pelas reformas de ampliação da administração estatal cuidavam de enfrentar as concepções conservadoras que naturalizavam hierarquias biológicas como causação das distinções socioeconômicas.

Afrânio Peixoto se vale da credibilidade das ciências e da abertura que o liberalismo oferecia para fundamentar sua própria trajetória. Sua ascensão fulminante é prova de que ele manejava com maestria preceitos científicos de diferentes campos do conhecimento e de que fora capaz de construir extensas conexões profissionais e pessoais, que o tempo, aliado à frenética produção, trataram de consolidar.

Para Vieira e Roballo (2008), Peixoto consagra-se como intelectual ao reunir as características seguintes, síntese dos projetos e aspirações das elites dirigentes às quais se funde.

\footnotetext{
1) sentimento de pertencimento a estrato social específico (intelectuais), a partir da construção de uma identidade que - independente de credo, origem social e ideologia - se estrutura na competência, familiaridade e/ou formação para lidar com a cultura, seja ela artística, filosófica, científica ou pedagógica; 2) empenho e engajamento político, a partir de um sentimento de missão social; 3) por fim, defesa da centralidade da questão educativa/formativa no projeto moderno de reforma social. (VIEIRA e ROBALLO, 2006, p. 2471).
}

De nosso ponto de vista, seu romance A Esfinge expõe seu enlevado estranhamento com o universo cotidiano e a vida provada das elites da Capital Federal. Consideramos tal romance uma etnografia literária, um mapeamento dos costumes e dos dilemas causados pelas novas ideias e modas do circuito social da capital, por onde ele transita, o que lhe assegurava autoridade para falar a respeito. 
Do muito que tem sido dito sobre Afrânio Peixoto, parece consensual na historiografia que sua dedicação ao tema da educação da mulher resulte das injunções dos projetos políticos para a nação ${ }^{10}$, preocupada em designar o curso das mudanças por que passa a condição da mulher então, conforme afirma Elizabeth Sousa Abrantes:

A intervenção de Afrânio Peixoto nesses debates higienistas se deu pelos discursos médicos e pedagógicos, direcionando-os especialmente para a mulher, já que esta era considerada o pilar da família. Seu entusiasmo pela ciência, em especial a medicina, era fortemente expresso em suas obras de educação, onde aplicava os mesmos conceitos utilizados em seus livros sobre saúde e higiene, numa clara sintonia com os demais adeptos da racionalidade médico-higiênica. (ABRANTES, 2010, p. 147).

Tal visão somente é possível quando consideramos sua obra no conjunto, mas quando observamos o jovem Afrânio, tendemos a considerar que os assuntos espinhosos e que desassossegavam o establishment eram mais atraentes para o contumaz médico e professor, pois, se por um lado urgia à nação enfrentá-los, por outro lado, essa conjuntura propiciava ao autor o ambiente necessário à exibição de suas qualidades intelectivas e personalistas. $\mathrm{Ou}$, como afirma Roberlayne Roballo:

\footnotetext{
Nesse sentido, empenhou-se no estudo de temas como a eugenia, higiene, sexualidade (homossexualidade, adultério e defloramento), puericultura, loucura, criminalidade e a educação da mulher. Esses temas tinham uma forte ressonância política, pois incidiam sobre reformas urbanas, políticas de controle e sobre a repressão dos sujeitos considerados "doentes sociais", bem como na organização das famílias, no disciplinamento das massas e das mulheres. (ROBALLO, 2010, p. 145-6).
}

De posse dessas referências, analisamos a adequação das temáticas sobre a mulher à literatura por ele produzida, considerando o recorte das duas obras, já mencionadas. Do seu manual Elementos de Medicina Legal, publicado pela primeira vez em 1911, buscaremos dados para compor interlocução a respeito da condição da mulher com o romance $A$ Esfinge, publicado no mesmo ano. Nosso propósito é examinar como Afrânio participa do debate nestas diferentes frentes observando suas defesas e recusas aos papeis imputados à mulher. Neste recorte, nos atemos ao Afrânio até 1911, exclusivamente, portanto. Contudo, consideramos que este recorte, ao colocar sob foco a produção de um jovem Afrânio de 34 anos, pode ajudar a entender suas contradições apontadas pela historiografia para posterior compreensão do percurso do desenvolvimento de seu pensamento.

\section{3 - A Capital Federal nos anos 1910}

À época do lançamento de ambos os livros, em 1911, o Rio de Janeiro passava por um processo de revitalização da qualidade de vida da população através de campanhas e estudos de médicos, principalmente sanitaristas, políticos e de setores da burguesia. $\mathrm{Na}$ realidade, esse movimento vem desde o final do século XIX, tendo continuidade até as primeiras décadas do século XX. Esse período é caracterizado por um projeto político que tinha por objetivo transformar o país numa nação civilizada. Em consequência dessas mudanças, um novo perfil de conduta social continuava a ser traçado a partir dos ideais higienistas, provocando severas alterações no que tange à organização da família, à 
implementação de uma política de saúde física e mental que garantisse corpos saudáveis com a finalidade de manter a força de trabalho para a construção da nação brasileira.

Dentro desse contexto surge a figura da mulher bem educada como alicerce de uma boa estrutura familiar, obedecendo ao marido e cuidando dos filhos. Mesmo às mulheres que tinham acesso à educação, a opção mais acessível de educação escolar era o Curso Normal, em contraposto às possibilidades de acesso do homem à escolaridade e à continuidade desta, conforme aponta Soihet,

\footnotetext{
Enquanto os homens cursavam o ensino secundário, que visava o acesso aos cursos superiores, as moças, em sua maioria, encaminhavam-se para as escolas normais, destinadas à profissionalização e/ou ao preparo para o lar. (Soihet, 1997, pp.8-9)
}

O mundo público era predominantemente masculino, mas havia mudanças em curso. Desde a Proclamação da República, sucessivas crises políticas promoveram revoadas desestabilizadoras e de reajustamento dos quadros políticos. Tal seleção buscava assegurar a evasão dos aguerridos e "permutação em larga amplitude dos grupos econômicos" (SEVCENKO, 2003, p. 37). Segundo este autor,

\begin{abstract}
Serão 'homens novos', vindos à tona com a nova situação, que irão dar o tom geral à ordem que se criava, marcando o novo sistema de governo com o timbre definitivo do arrivismo sôfrego e incontido (...). No decorrer do processo de mudança política, os cargos rendosos e decisórios - antigos e novos - passaram rapidamente para as mãos desses grupos de recém-chegados à distinção social, premiados com as ondas sucessivas e fartas de "nomeações", "indenizações", "concessões", "garantias", "subvenções", "favores", "privilégios" e "proteções" do novo governo. (SEVCENKO, 2003, p. 37-8).
\end{abstract}

É um momento de contradições. Ao mesmo tempo em que promovia novos homens e se revezavam as elites, o modelo do homem burguês se consolidava como o do homem bem sucedido, consagrando "o arrivismo agressivo sob o pretexto da democracia" (SEVCENKO, 2003, p. 37). Essa nova cidade, que instala e desinstala riquezas voláteis, que cresce desordenada, vê diluídas algumas das clássicas distinções sociais e disseminarem-se pelas diferentes classes sociais os valores da igualdade reclamada principalmente pelos escritores e jornalistas representantes desse novo grupo de homens aburguesados pelas apostas liberais e democráticas. Neste cenário, ganha importância fundamental o capital das relações sociais, a formação escolar e os bens culturais são decisivos para a ocupação dos cargos cada vez mais concorridos frente à promoção dos parentes pobres e mais afastados das elites (MICELI, 2001).

É nesta sociedade que os livros cumprem um lugar específico na formação do homem nacional, seja ele didático ou literário, um projeto de civilidade orienta linhas de publicação das casas editoras, ao lado de outras linhas mais comprometidas com a publicação do exótico ${ }^{11}$.

Além disso, e ainda com Nicolau Sevcenko, parte considerável da produção literária do país era feita no Rio de Janeiro, voltada à própria cidade. Nela, a crise de valores morais se materializa na corrosão da "sensibilidade romântica tradicional" (Idem). As transformações sociais são expostas na minudência das relações interpessoais: 


\begin{abstract}
A aceleração do ritmo de vida pôs fim aos longos noivados. A substituição da sociabilidade dos salões pela das ruas, praças e jardins acabou com os namoros e instituiu o império do flirt. (...) Os suicídios por amor (...) já são cobertos do maior ridículo. O jornalismo, com sua curiosidade pelo lado vulgar dos homens, acabou com os heróis. (...) O próprio cavalheirismo se dissolveu diante da maré do "feminismo", dos transportes coletivos e da entrada da mulher no mercado de trabalho da cidade. (SEVCENKO, 2003, p. 120-1).
\end{abstract}

Com estas vertentes editoriais chegamos aos livros em questão. $\mathrm{O}$ autor, com estes seus dois trabalhos, atende às duas linhas. Se, por um lado, a cidade carece de ordem, controle e os eventos cotidianos demonstram a urgência em formar quadros de peritos para a investigação de crimes e delitos; por outro, a cidade se alimenta das novidades que a modernidade proporciona, especialmente quanto aos valores morais que orientam os comportamentos de homens e mulheres. Estas últimas passam por um excepcional momento no mundo ocidental, onde empreendem pesadas campanhas pela conquista de direitos políticos e de espaço na esfera pública.

\title{
4 - Medicina Legal n'A Esfinge
}

\section{1 - Medicina Legal}

O manual amplamente utilizado na Faculdade de Medicina do Rio de Janeiro foi reeditado por mais de três décadas e contabiliza nove edições até 1946. Nele, Afrânio faz circular entre os estudantes de Medicina, com pressupostos de ciência, os preconceitos sociais, raciais e de gênero em voga à época. A suposta cientificidade da ciência criminológica do final do século XIX e início do XX dava suporte à legitimação dos valores socioculturais dos grupos hegemônicos com o propósito de perpetuar a ordem social, justificando preconceitos e perseguições às classes pobres e às raças consideradas inferiores, assim como as distinções que mantinham a hierarquia entre homens e mulheres.

No Brasil, Raimundo Nina Rodrigues e seus seguidores foram responsáveis pela defesa e vulgarização das teses que procuravam explicar o "atraso" da sociedade brasileira frente à moderna civilização ocidental. Afrânio Peixoto iniciou sua carreira como discípulo deste médico, mas ao longo de sua vida, ele oscila entre as tendências progressistas que varrem o mundo ocidental nas primeiras décadas do século XX e os ranços conservadores que mantêm o Brasil na inércia do desenvolvimento. Quando Afrânio Peixoto mudou-se para o Rio de Janeiro em 1902 foi, como já dissemos, para ocupar o cargo de Inspetor de Saúde Pública, a convite de seu outro mestre, Juliano Moreira.

O livro Medicina Legal é, nas palavras do próprio autor, "um livro didático para instrução de futuros peritos e magistrados" ${ }^{12}$. Ou seja, médicos que optam pela medicina legal como especialização. Campo interdisciplinar, a Medicina legal é ciência aplicada da criminologia, de interesse médico e forense. Afrânio vê-la como "conjunto de aquisições, de varia origem, para fim determinado (...) na prática forense" ${ }^{13}$. O livro teve um volume II, Psicopatologia Forense, escrito em $1916^{14}$, não explorado neste trabalho.

Segundo o autor, o trabalho do perito é determinar as causas de atos criminosos pela leitura das pistas deixadas como marcas no corpo humano, preferencialmente, e declará-las à justiça. Na Advertência do livro, destaca os limites da função do perito: 


\begin{abstract}
Nada mais ela [a justiça] lhe pede e é demasiado quem, não sabendo cumprir a próprio dever, exerce o dos outros, pondo-se a discutir leis e ajeitar textos, sempre passíveis de interpretações dúbias. Relativamente às leis, o dever estrito é acatá-las e servi-las; se são mal feitas, trabalho inútil é investir contra elas, quando não é oportuno. Chegado o momento de sua reforma pelo poder competente, o perito, que não é diferente de qualquer outro cidadão, tem o direito e o dever de intervir, discutir, reclamando lei melhor e mais justa. (PEIXOTO, 1923, p. 5).
\end{abstract}

No entanto, seu manual de medicina legal é um ajuste nos costumes, um refreamento no caos instalado na cidade. Organizado como um manual de civilidade aos cidadãos peritos, ele distribui os capítulos segundo uma escala de valores morais imputados às condutas do homem comum e ao médico enquanto profissional:

- Direitos e deveres da espécie à procriação. Delitos sexuais;

- Direitos e deveres do indivíduo à saúde e à vida. Delitos corporais;

- Elementos de prova;

- Direitos e deveres dos médicos;

- A função pericial no Brasil.

No exame do primeiro capítulo, "Direitos e deveres da espécie à procriação. Delitos sexuais", pelo que contém de mais explicitamente exposto quanto às estratégias de punição aos comportamentos "modernos". Subdividido em títulos, temos:

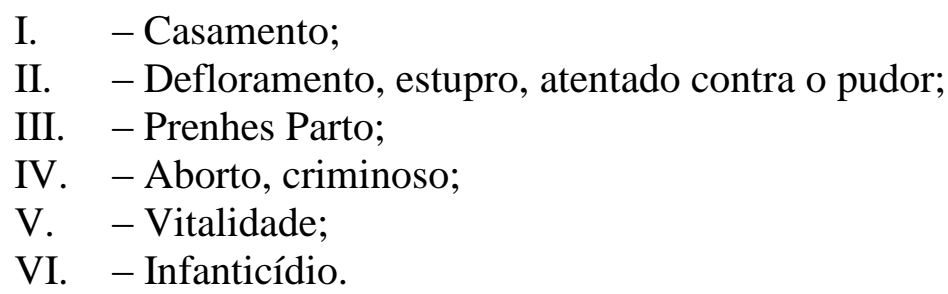

Entre a apresentação do código de leis vigentes sobre a matéria e a apresentação da anatomofisiologia dos órgãos reprodutores, ele discorre sobre os impedimentos legais que regulam os costumes no empenho dessas relações. No caso do casamento, os limites impostos pelo parentesco e idade, incapacidades físicas e mentais, doenças transmissíveis por herança ou contágio, sevícia e injúria circunscrevem um conjunto de anormalidades diante das quais as uniões conjugais poderiam ser invalidadas. $\mathrm{O}$ detalhado estudo himenológico, necessário para evitar pedidos infundados de anulação de casamento pelos maridos por "erro essencial sobre a pessoa", e as descrições das malformações genitais, Afrânio segue elencando as implicações morais transversas.

Como recurso de validação, o debate entre os especialistas transcorre em meio à descrição dos costumes quanto ao casamento em outros países. No caso da idade mínima legal para o casamento, ele apresenta o quadro I, a seguir.

QUADRO I ${ }^{15}$

\begin{tabular}{|l|l|l|}
\hline PAÍS & MULHERES & HOMENS \\
\hline Espanha & 12 & 14 \\
\hline Portugal & 12 & 14 \\
\hline Inglaterra & 12 & 14 \\
\hline
\end{tabular}




\begin{tabular}{|l|l|l|}
\hline Grécia & 12 & 14 \\
\hline Aústria & 14 & 14 \\
\hline Alemanha & 14 & 18 \\
\hline França & 15 & 18 \\
\hline Bélgica & 15 & 18 \\
\hline Itália & 15 & 18 \\
\hline Brasil & 16 & 18 \\
\hline Romania & 16 & 18 \\
\hline Russia & 16 & 18 \\
\hline
\end{tabular}

O Brasil se alinha às nações desenvolvidas e modernas ao retardar a idade nubente de homens e mulheres em defesa do amadurecimento físico e psicológico. Combate tanto os casamentos fruto de acordos financeiro, social ou político entre as famílias, quanto o sexo fora do casamento. A respeito do quadro acima, Afrânio emite opinião sobre as relações precoces.

\begin{abstract}
Não tem nenhum valor para a fixação dessas pessoas a possibilidade de uma sexualidade temporã, ou mesmo oportuna, nas idades juvenis. Mas a consideração deve certamente merecer o facto, que importa à espécie e ao indivíduo, das consequências para a vida, de práticas sexuais prematuras. Não é exigível sómente que os indivíduos já sejam capazes de procriar, mas que o façam sem prejuízo de sua saúde e sem desvantagem para a descendência. (PEIXOTO, 1936, p.16)
\end{abstract}

O destaque ao fato de que casamentos precoces são nocivos aos cônjuges, à fecundidade e à vitalidade de seus filhos e para a mortalidade infantil muito alta, conforme observamos no quadro II, abaixo, aponta investimentos delimitar condutas que contribuam para o desenvolvimento nacional:

\begin{tabular}{|c|c|c|}
\multicolumn{3}{|c|}{ QUADRO II ${ }^{16}$} \\
\hline $\begin{array}{c}\text { IDADE DAS } \\
\text { MÃES }\end{array}$ & MÉDIA & MORTALIDADE \\
De nascimento por casal & Dos filhos \\
\hline Antes dos 16 anos & 4,40 & $28,0 \%$ \\
\hline Dos 16 aos 20 & 4,63 & $20,0 \%$ \\
\hline Dos 20 aos 24 & 5,21 & $18,8 \%$ \\
\hline
\end{tabular}

A elevada mortalidade infantil no Rio de Janeiro em 1900, da ordem de 77,02 \%, são atribuídos, em sua maioria, à precocidade dos casamentos. Nenhuma nota às condições de vida população ou à qualidade dos serviços de saúde, educação, moradia ou trabalho, embora enfatize que esta precocidade também era mais evidente nas áreas rurais. Como prova das benesses da modernidade, oferece dado de que nos centros civilizados, as pessoas casam-se cada vez menos e mais tarde. Em seguida, discorre a respeito das vantagens morais do casamento.

No capítulo dedicado ao defloramento, 26 páginas são destinadas à tipologia do hímen, assim como às circunstâncias verossímeis e inverossímeis de ruptura e dilaceramento deste. $\mathrm{O}$ detalhamento é revelador das contendas em torno da questão e a abordagem enfatiza as mistificações e inverdades sobre o tema à época.

Segundo Peixoto, os delitos carnais se dividiam em quatro termos: $1^{\circ}$ Ultraje público ao pudor - quando havia ofensa aos bons costumes por meio de exibições, atos, gestos 
obscenos, em lugar público, escandalizando à sociedade, embora sem agravo individual; $2^{\circ}$ Defloramento - quando há cópula carnal com mulher virgem, de 16 a 21 anos, empregando sedução, fraude, engano; $3^{\circ}$ Estupro - cópula natural - com mulher virgem, menor de 16 anos ou com mulher, virgem ou não, de qualquer idade, com emprego de força física ou de meios que impossibilitem a resistência e a defesa, juridicamente capitulados de violência; $4^{\circ}$ e último, Atentado contra o pudor - São atos ou práticas obscenas em pessoa de um, ou outro sexo, de menor de idade, ou mesmo de maior, por meio de violência ou ameaças para o fim de satisfazer paixões lascivas ou costumes depravados.

O último capítulo do livro, Direitos e deveres dos Médicos, no item I - Ética e economia profissional, o autor destaca o papel do médico na sociedade e seu compromisso com o Estado e a nação. Lembra que têm o monopólio da doença para combater a prática ilegal da medicina, porque:

A ignorância das massas assim o exige ainda, acessíveis que são ao engano, á fraude, ao charlatanismo. Esta providencia tende a cessar com a instrução difundida, que deve dar ao povo a consciência de si mesmo. (PEIXOTO, 1936, p. 385).

Segue destacando a importância do segredo médico, especialmente na função pericial. Termina expondo as proximidades da perícia com a antropologia criminal e psiquiatria clínica.

\section{2 - A Esfinge}

As defesas dos argumentos informados pela ciência médica no romance devem obedecer outros marcadores. No romance $A$ Esfinge o autor expõe sua impossibilidade de compreender o universo feminino. O jovem escritor resume no título diferentes aspectos do que lhe vai à razão de mais inquietante quanto ao desconhecido (ou ainda não elaborado) universo feminino. Essa diligência, empreendida ao longo da vida e que daria outros frutos apaziguando esta impotência, caminha na suposição de ter avançado, de ter, ao menos, descoberto os meios de abordar o tema e aproximar-se dele com autoridade. A título de apontar sua insistência no tema, a produção ensaística de Afrânio sobre as mulheres de duas décadas mais tarde o mostram com mais firmeza e autoridade ${ }^{17}$, mas não é deste Afrânio que tratamos aqui.

Neste romance de ingresso às letras e à imortalidade, ele ainda exibe seu pasmo ante os costumes triviais das elites. $\mathrm{O}$ velho Lisboa, personagem masculino que representa $\mathrm{o}$ melhor amigo da protagonista, descrito como "um velho conservador, tolerante e otimista, de uma bondade perdulária” (Peixoto, 1911, p. 34), assim observa:

O flerte era a iniciação necessária aos moços: assim eles vinham a casar,empenhando-se num jogo perigoso em que acabam sempre perdendo... Espécie de manobra que faz os destemidos para a guerra, em que devem morrer. Das condições econômicas mais difíceis e do absurdo natural do casamento indissolúvel resulta que hoje a gente casa cada vez menos: sem o flerte, espécie de escorva ou provocação necessária, reduzir-se-ia então ... lamentavelmente... E os pais, por consequência, o ajudam. (PEIXOTO, 1911, p. 39) 
E o personagem continua, acrescentando adiante:

O casamento é associação sem interesse recíproco, porque se propõe a dar ao amor, que é a vida agitada do desejo, satisfação tranquila, oportuna, sem cuidados. Insosso e desenxabido, por isso mesmo. Daí tantos adultérios, escândalos crueldades de outros tempos, e crimes bárbaros ainda hoje. (Idem)

Já o deputado do norte, Dr. Câmara, descrito pelo autor como "político de grande importância, homem de futuro", "um homem de maneiras compostas, com precoce gravidade e ar superior de descrição", assim se expressa sobre as mulheres:

A experiência lhe ensinara que as mulheres de mais recanto gostam de ser desrespeitadas na intimidade. São infelizes os amores respeitosos. Dão- se mais facilmente a quem as toma com violência, do que quem as suplica com doçura. Amam com a cabeça os homens polidos e delicados e adoram com o resto do corpo os brutais e os violento. E só porque a fortuna é mulher, que ajuda os ousados. (Idem, p. 91)

Já o poeta Luis Macedo, dispara, numa conversa entre diplomatas e homens das letras: O casamento, o adultério, com ou sem divórcio passam de moda... já não há poesia do recato e da novidade, que dava a ilusão do amor... Este só se encontra hoje, talvez entre mundanas. De fato, a imoralidade anda agora principalmente com a gente fina... vive em salões. Na rua, no corso, nos teatros, as cocottes têm ar honesto, falam bem, com timidez, discrição, e até aparentam acreditar no amor...pelo menos praticam publicamente a virtude... Nas praças, nos jardins, nos carros, nas festas, são simples e honestas burguesas... Nos salões, entretanto, a boa gente aperta-se, declara-se, namora, beija-se e, se não faz mais, é simplesmente por questão de mobiliário. (Idem, p.59)

$\mathrm{O}$ assunto era polêmico e movimentava a sociedade, especialmente porque o casamento civil, instituído no Brasil em 1890, também encontrou no Decreto 181, do mesmo ano, permissão para a separação de corpos, uma espécie de "divórcio" que se contrapunha às leis da Igreja. O desquite foi introduzido no Brasil pelo Código Civil Brasileiro de 1916, uma variação do divórcio, mas com capacidade para pôr fim aos acordos maritais. Em 1911, portanto, o assunto estava em pauta com frequência, assim como os casamentos por acordo e os motivados pelos sentimentos.

Na passagem do século XIX para o XX, ocorrem mudanças comportamentais e o casamento não poderia ficar imune a elas. "Os casais começam a se escolher porque as relações matrimoniais tinham sido fundadas no sentimento recíproco. O casamento de conveniência passa a ser vergonhoso e o amor... bem, o amor não é mais uma ideia romântica, mas o cimento de uma relação" (DEL PRIORI, 1997, p. 231).

Numa entrevista, concedida anos depois, à Revista A Ordem, Afrânio se diz favorável ao divórcio:

- É um remédio necessário o desquite ou a separação dos corpos se os cônjuges viram em inimigos depois da sociedade matrimonial. Melhor vale que se vão, cada um do seu lado, de que suportarem o inferno de uma convivência odiosa, se chegarem a esta dolorosa situação. A lei divina e a humana se associam para facilitar tal separação, remédio desesperado, mas necessário. (A Ordem, 1920).

Era oportuno, à época da escrita do romance, colocar seus personagens para discutir o que a sociedade está negociando, visando apresentar argumentos contra e a favor e falar 
sobre o papel da mulher. Nesta revista católica, e após a aprovação do desquite, ele acrescentar tratar-se de medida extrema.

\section{5 - Considerações Provisórias}

Entretanto, o caráter limítrofe de seus escritos e estilos de vida não tinham componentes que atraíssem homens como Afrânio Peixoto, que fazia questão de reafirmar sua juventude irreverente através de firulas supérfluas, mas que buscava a intimidade do poder e a distância necessária à autonomia de uma arte crítica capaz de denunciar a estrutura social e os que a mantêm. Neste sentido, a aparência de contestador esconde o exibido narciso, Mas o universo da literatura da cidade

A Esfinge conota certo espanto do autor ante a trivialidade do estilo de vida dos snobs - e também a classe dirigente do país - ambiente que passou a frequentar quando veio para o Rio de Janeiro. Mas é também uma maneira de mostrar sua compreensão das redes de relações e dos acordos tácitos em trânsito na sociabilidade da Capital Federal. Nos protagonistas, o autor adéqua novidade e tradição na justa medida do debate, sem os escândalos e bizarrices da literatura naturalista corrente e sem o tom antiquado da tradição conservadora de boa parte da elite. Sua experiência de homem "transgressor" de costumes - acentuada em seu passado recente e que procurava encontrar a inflexão adequada provavelmente o ajudou a mover-se por entre os debates acerca dos papéis sociais para homens e mulheres, procurando avançar no possível ante estas elites que apostavam em sua capacidade de inovar conservando e sempre de acordo com seus próprios interesses. Os demais personagens formam a constelação de tipos que realçam os protagonistas: infelizes, vulgares, fracassados, perdidos...

Medicina Legal aponta para os lugares de risco de uma sociedade em rápido processo de mudança. Devassidão, depravação dos costumes, conspurcação moral, laceração da sociabilidade. No cerne, o caminho para que não se percam os culpados de vista, para que a justa punição seja aplicada, para que os bons costumes encontrem fronteiras. Não é a lei que está em questão, mas a moralidade social e os custos do seu abandono. A noção de medicina aqui sobrepuja o direito ao colocar certa compreensão de "saúde integral" como mola mestra da condução das sociedades.

As duas obras mostram a disposição do jovem Afrânio às controvérsias. A um só tempo, provocador e conservador, ele desafiou e infringiu regras e as demarcou à moda dos modernos de sua estirpe, liberal e austero. Nada mais adequado. Com tamanha capacidade para fazer lobby e marketing pessoal, parte considerável do seu potencial intelectual, seria estranho se não conseguisse espaço, numa ocasião em que os postos de comando e direção se multiplicavam na estrutura da aparelhagem do Estado. Um homem que se fez à justa medida dos anseios das elites dirigentes, tanto mais propensas a entender o que estava acontecendo na sociedade, desde que isto implicasse em manutenção dos estabelecidos, quanto a conceder permanência aos outsiders dotados de talentos expressivos.

\section{6 - Referências}

ABRANTES, Elizabeth Sousa. A Educação da Mulher na Visão do Médico e Educador Afrânio Peixoto. Revista Outros Tempos. Volume 7, número 10, dezembro de 2010. Dossiê História e Educação. 
ARANHA, Maria Lúcia de Arruda. História da Educação e da Pedagogia: Geral e Brasil. $3^{\text {a }}$ ed. Rev. AmpL. São Paulo: Moderna, 2006.

BAKHTIN, Mikhail. "Os Gêneros do Discurso". In: Estética da Criação Verbal. 2a. Ed. São Paulo: Martins Fontes, 1997. (Coleção Ensino Superior).

BRITO, E. Z. C. “A Criminologia e a Construção de Gênero, Classe e Raça”. In: Salvador. I Simpósio Internacional - O Desafio da Diferença - Articulando Gênero, Raça e Classe. v.1. 2000 , p. $27-57$.

. "A Criminologia Informa a Literatura de Afrânio Peixoto". In: COSTA, Cléria B.; MAGALHÃES, Nancy A. Contar História, Fazer História. Brasília: Paralelo $15,2001$.

BROCA, Brito. A Vida Literária no Brasil - 1900. 4a Ed. Rio de Janeiro: José Olympio, 2004.

CANDIDO, Antonio. Literatura e Sociedade. Rio de Janeiro: Ouro sobre Azul. 2005.

CHOR, Marcos Maio. "Afrânio Peixoto: notas sobre uma trajetória médica”. Revista da SBPC, n. 11, 1994, p. 75-81. Disponível em: <www.sbhc.org.br/arquivo/download?ID_ARQUIVO=254>. Acesso: 28/08/2012.

COUTINHO, Afrânio. "Afrânio Peixoto, Entre a Cidade e o Sertão". In: Afrânio Peixoto Romances Completos. Rio de Janeiro: Aguilar, 1962.

Dicionário Histórico-Biográfico das Ciências da Saúde no Brasil (1832-1930)

Casa de Oswaldo Cruz / Fiocruz. Disponível em: http://www.dichistoriasaude.coc.fiocruz.br.

GADOTTI, Moacir. História das Ideias Pedagógicas. São Paulo: Àtica, 1999.

GONDRA, José G.; SOOMA SILVA, José Claudio. "Escritas da História: um estudo da produção de Afrânio Peixoto (1916-1947)". IN: GONDRA, José G.; SOOMA SILVA, José Claudio (Orgs.). História da Educação na América Latina: ensinar \& escrever. Rio de Janeiro: EdUERJ, 2011.

GOUVEIA, Almeida. Afrânio Peixoto - Cavaleiro da Medicina Social... E de Mulheres Esfinges... Bahia: Mensageiros da Fé Ltda, 1976.

LOPES, Eliane Marta Teixeira. "Júlio Afrânio Peixoto". In: FÁVERO, Maria de Lourdes de A.; BRITTO, Jader de M. Dicionário de Educadores do Brasil. Rio de Janeiro: UFRJ/MEC-INEP, 1999.

MATTA, Carmen. Rio de Janeiro, solo configurador da literatura nacional. Revista Rio de Janeiro, n. 10, maio-ago. 2000. p. 259-278.

MICELI, Sergio. Intelectuais à Brasileira. São Paulo: Companhia das Letras, 2001. 
RIBEIRO, Leonídio. Afrânio Peixoto. Rio de Janeiro: Conde, 1950.

NORBERT, ELIAS. Mozart. Sociologia de um Gênio. Rio de Janeiro: J. Zahar, 1995.

PEIXOTO, Afrânio. A Esfinge. 12 ed. São Paulo: Clube do Livro, 1978. 1ª ed. 1911.

PEIXOTO, Afrânio. Elementos de Medicina Legal. v. 1, 4ª ed. e $7^{\mathrm{a}}$ ed. Rio de Janeiro: Francisco Alves, 1923 e 1936.

ROBALlO, Roberlayne de Oliveira Borges. Manuais de História da Educação da Coleção Atualidades Pedagógicas (1033-1977): Verba Volant, Scripta Manent. Tese de Doutorado. Universidade Federal do Paraná. Curitiba, 374 fls, 2012. Disponível em: $<$ http://www.recantodasletras.com.br/artigos/1625456>. Acesso: 25/05/2014.

SANTOS, Maria Aparecida dos. Entre a Ciência e o Preconceito. Afrânio Peixoto, epilepsia e crime. Pontifícia Universidade Católica, do Rio de Janeiro, 2008. Monografia. Disponível

em: $<$ http://www.historiaecultura.pro.br/cienciaepreconceito/producao/aparecidasantosmonogr afia.pdf>. Acesso: 20/11/2008.

SEVCENKO, Nicolau. Literatura como Missão: Tensões sociais e criação cultural na Primeira República. $2^{a}$ edição, $2^{a}$ Reimpressão. São Paulo: Companhia das Letras, 2003.

SILVA, Maria de Lourdes. Educação, Sexo e Feminices - Representações da Mulher na Produção Literária de Mme. Chrysanthème e Afrânio Peixoto nas Primeiras Décadas do Século XX. Projeto de Pesquisa. Rio de Janeiro, 2013.

SILVA, Maria de Lourdes; MOREIRA, Helena M. A., AMANCIO, Cristiane da Fonseca. Afrânio Peixoto em A Esfinge (1911): Imagens da Educação da Mulher na Primeira República. Trabalho apresentado no III Encontro de História da Educação do Estado do Rio de Janeiro (III EHEd-RJ), na Pontifícia Universidade Católica do Rio de Janeiro (PUC-Rio), SET-2013.

SOIHET, Rachel. "Violência simbólica. Saberes masculinos e representações femininas". In: Revista Estudos Feministas. Vol.5, No $1,1^{\circ}$ semestre de 1997. Rio de Janeiro, Instituto de Filosofia e Ciências Sociais - IFCS/UFRJ. p. 7-29

VIEIRA, Carlos Eduardo; ROBALLO, Roberlayne de Oliveira Borges. História e História da Educação no projeto de formação de professores na década de trinta no Brasil: problematizando as Noções de Afrânio Peixoto. Anais do VI Congresso Brasileiro de História da Educação, Uberlândia, Minas Gerais, 2006. Disponível em: <http://www2.faced.ufu.br/colubhe06/anais/arquivos/219RoberlayneOliveiraRoballo_e_Ca rlosEduardoVieira.pdf>. Acesso: 10/06/2014.

Notas

1 - Professora Adjunta da Faculdade de Educação da Universidade do Estado do Rio de Janeiro - UERJ.

Email: Lullua2@yahoo.com.br 
2 - Graduada em Pedagogia pela UERJ. Mestranda do PPGEB do CAP-UERJ. Email: lenamarialves21@ hotmail.com

3 - Em 1890, o médico Cesare Lombroso (1858-1909) lançou seu livro $O$ homem de Gênio, no qual aproxima as qualidades especiais dos gênios, loucos e criminosos, afirmando que estes são resultados da degenerescência e da epilepsia. Nina Rodrigues foi seu maior divulgador no Brasil e Afranio Peixoto em sua tese de doutoramento, Epilepsia e Crime, replicava suas ideias.

Neste trabalho, o autor propõe a "medicamentação do crime" (LOPES, EMT. 1999, p. 320). Ou seja, para o autor da perda da razão provocada pelas crises da doença, que suscetibilizavam seu portador às ações imorais e/ou ilegais, deveriam ser controladas através do dispositivo medicamentoso.

4 - Na legenda se lê: "Afranio era ambidestro. Aí o vemos corrigindo provas com a mão esquerda". In:

Coutinho, A. 1962, p. 29.

5 - Compreendemos que uma ampla formação não era prerrogativa somente de Júlio Afrânio Peixoto. Segundo Aranha (2006), na antiguidade os gregos desenvolveram um processo formativo que primava pela formação do homem integral. Esse processo ficou conhecido como Paidéia. Gadotti (1999) aponta na mesma direção, nos dizendo que: a escola primária destinava-se a ensinar os rudimentos: leitura do alfabeto, escrita e cômputo. Os estudos secundários compreendiam a educação física, a artística e a dança. Os estudos literários compreendiam o estudo das obras clássicas, principalmente de Homero, a filologia (leitura, recitação e interpretação do texto), a gramática e os exercícios práticos de redação. Os estudos científicos apresentavam a matemática, a geometria, a aritmética, a astronomia. No ensino superior prevalecia o estudo da retórica e da filosofia. (GADOTTI, 1999, p.30-31). No Brasil os modelos formativos se inspiravam nos processos educativo grego, submetendo os indivíduos a ampla formação enciclopédica.

6 - SANTOS, 2008, p. 26-27.

7 - Neste caso, estamos considerando a medicina como uma esfera do conhecimento com capacidade para adentrar outros campos e fazê-los funcionar segundo seus interesses e sob sua influência.

${ }^{8}$ - Sevcenko nos conta que essas orientações representavam polaridades de concepções e posicionamentos difíceis de encontrar, pois que a grande maioria dos escritores, jornalistas e membros das elites preferiam a ambiguidade da combinação entre esses referentes. Um bom exemplo disto é o darwinismo social que materializa o mito de uma teoria geral do comportamento humano, o principal credo da Belle Époque (SEVCENKO, 2003, p. 100), sob controle dos cientistas, permitindo planejar o país do futuro.

9 - Nesta categoria, podemos colocar os escritores já mencionados João do Rio e Lima Barreto. O primeiro, homossexual e o segundo, mulato alcoolista. Podemos trazer também algumas escritoras mulheres que, a despeito da condição aristocrática de nascimento, tiveram que garantir o sustento seu e de suas famílias com trabalho pesado das repartições dos jornais, como as escritoras mãe e filha Carmen Dolores e Madame Chrysanthème.

10 - A este respeito, ver os trabalhos de ABRANTES, Elizabeth S. (2010), GONDRA, José G. (2011).

11 - Ver BROCA, Brito, 2004.

12 - PEIXOTO, A. Medicina Legal, $4^{\text {a }}$ Ed., 1923, p. 5.

13 - Idem.

14 - Seu livro de Psicopatologia Forense editado pela Francisco Alves, teve 7 edições em duas décadas e vendeu cerca de 23 mil exemplares.

15 - Fonte: PEIXOTO, A. Medicina Legal, 1923, p. 16.

16 - Idem, p. 17.

17 - Ver os livros Ensinar a Ensinar (1923) e A Educação da Mulher (1936).

Anos mais tarde, em 1940, com sua metáfora de que a "literatura é o sorriso da sociedade" (PEIXOTO, 1947, p. 5), Afrânio defende que a literatura expressa a condição de vida, o estado de espírito da sociedade, podendo ser feliz ou apreensiva. Tal concepção explica a opção do romance em tela, de dedicar-se à representação da vida privada das elites fluminenses, trazendo o foco para as questões de ordem moral antes da socioeconômica.

Recebido: julho-15 Aprovado: setembro-16 